\title{
Big Data and the Demand for Court and Legal Services
}

\author{
Carmen Vargas Pérez \\ Department of Applied Economics IV, Complutense University of Madrid \\ Juan Luis Peñaloza Figueroa \\ Department of Statistics and Operations Research II, Complutense University of Madrid
}

\begin{abstract}
Law and Economics literature has dealt with the factors determining the demand side of justice for more than 40 years. Both theorists of economic analysis and applied researchers have focused on the different variables that influence demand, such as direct and indirect costs, the chances of winning, the chances to settle out of court and delay, among others, which in turn may be affected by the judges, lawyers and parties incentives. Many of these variables cannot be directly observed by the ordinary citizen. In this paper, we contribute to the Law and Economics literature by showing that Big Data must be considered a new way to approach demand for court and legal services as it introduces new criteria to take into account and a new way to make the decision of whether or not to proceed to trial.Keywords: BIG DATA, Law and Economics, Demand for Court Services, Demand for Legal Services
\end{abstract}

\section{JEL Classification: K40 K49}

\section{Introduction}

Since the 1970s, numerous papers have examined the possible determinants of the demand for court services. Under the premise that agents are rational, they have studied the incentives to go to trial or reach an out-of-court settlement.

The relevance of litigation that should not be there, or that some conflicts that should go to court do not actually do, is not small. Firstly, because litigation that should not occur generates social and private costs, which could be channelled to other uses, increasing the efficiency in the use of public and private resources. And because this litigation, inefficient because it is unnecessary, can increase the delays of the judicial system, reducing its ability to effectively solve other problems that do require the decision of a judge. And secondly, because disputes that do not reach the courts, even though they should, imply that a group of individuals or companies have breached a contract or broken a law and got away with it, whereas the victims do not receive the justice they deserve.

Decisions on whether or not to go to trial depend on, among others, the estimates of the costs of going to trial, the estimates of the chances of winning, the estimates of the waiting times to obtain a court judgement, the believe that obtaining a judgment means that the defendant will automatically pay what the sentence states ${ }^{1}$ or the belief that no tax must be paid on the amounts received after the trial (which includes the winning party's costs paid by the losing party). That is to say, the demand for court services crucially depends on the information parties have (and the estimations they make) on different variables that are often unknown to a greater or lesser extent and/or factors that are not under their control, even after filing the lawsuit and during the legal proceedings.

In this paper, we contribute to the Law and Economics literature by showing that Big Data must be considered a new way to approach the demand for court and legal services as it introduces new criteria to take into account and a new way to make the decision of whether or not to proceed to trial. As we will show later, the fact that Big Data allows agents (plaintiffs

1 Vargas and Peñaloza (2004) address the economic and social costs of not complying with judicial decisions, making estimates with Spanish data. 
and defendants) to obtain much more precise information, both on costs (money, time, stress,...) and on the legal proceedings and the chances of achieving a certain outcome in their specific cases, is significantly changing the decision to litigate and introducing a new logic in the behaviour of the consumers of legal and court services. In addition, the possibility for clients of legal services to access that Big Data in turn results in suppliers changing their strategies with respect to clients and the market in general.

In Section 2 of this paper, the influence of various factors on the demand for court services according to the most standard theory in the absence of Big Data is briefly described. In Section 3 we discuss the several ways in which such effects and behaviors are modified because of the recent incorporation of the Big Data logic and the access to this massive amount of information. Finally, Section 4 presents some Conclusions.

\section{The Traditional Approach to Litigation and the Demand for Court Services}

The main variables that have traditionally been considered to determine the demand for court services are schematically presented in this Section. In the next Section, this will allow us to show how the decision criteria are modified, significantly in some cases, with the new appearance of Big Data in today's society.

Studies on this issue began more than forty years ago, being especially noteworthy the pioneering works of Landes (1971), Posner (1973), Gould (1973), Landes and Posner (1979), and Shavell (1982)1.

Pastor (2016) makes an interesting classification of the main factors affecting the demand for court services as follows:

** Information problems that result in differences in the parties' estimates of their chances of winning the case.

** Information problems that modify the parties' estimates about the amount at issue and the costs of litigating or reaching an agreement.

** The fact that litigation costs are low in relation to the costs of reaching an out-of-court agreement.

** Strategic behavior of the parties (and the number of lawyers ${ }^{2}$ ).

** Asymmetry of costs and amounts in general among parties.

** Agency problems, as a result of lawyers having interests different from those of their clients.

** The initial conflict itself, for example, a breach of contract, because someone considered that the expected benefits of doing so were greater than the expected costs, including the risk of being sued and the costs involved.

Other factors to mention may be the quality of legal precedents (Vereek and Muhl, 2004), the level of economic growth ${ }^{3}$, the allocation of court fees to the participating parties, the existence of legal protection insurances (Pastor 2016), court delay $^{4}$, the time preference, the general propensity to litigate (Buscaglia and Ulen 1997), the attitude towards risk and other factors affecting individual preferences, among others; not forgetting the interaction between supply and demand ${ }^{5}$, and the circular relationship between delay and the demand for court services (Vereeck and Muhl, 2000). Let us consider some of those factors.

\footnotetext{
${ }^{1}$ Surveys on the literature on the supply and demand for court services can be found in Shavell (2004) and Kaplow and Shavell (2002), or more recently in Voigt (2014).

2 For empirical results, see for example Mora \& Garoupa (2015).

${ }^{3}$ See for example the estimates of Rosales and Jimenez Rubio (2016) and Rosales (2017). There are potentially two opposite effects of economic growth on litigation. On the one hand, the greater the economic growth is, the more transactions and conflicts there will be, which indicates a positive correlation. But on the other hand, when there is a recession there are more unpaid debts and more lawsuits, which contributes to a negative correlation between these variables.

${ }^{4}$ In Vargas and Peñaloza (2007) we use Survival Analysis to assess the duration of civil cases in Argentina and then proceed to analyze the explanatory power of several variables.

${ }^{5}$ See Priest (1989) and Dakolias (1999) or the recent book by Pastor (2016).
} 


\section{- Estimation of the Chances of Winning the Case}

Many authors agree that the degree of optimism of the parties is a crucial determinant of litigation, and it is common to read that the degree of realism of their estimates will reduce the demand for court services. For example, on the one hand, Voigt (2014) concludes in his recent survey "if both parties have a realistic evaluation of their chances of winning (but also of losing) the case, then we should not observe any civil trials as a pre-trial bargain is expected to be systematically cheaper than taking the case to court". On the other hand, Pastor (1994) states that agreements occur when the perception of results coincide, or when the parties are very pessimistic; in particular, he concludes that lawsuits are less likely the smaller the difference $(\mathrm{Pa}-\mathrm{Pb})$ is, where $\mathrm{Pa}$ is the plaintiff's estimate of the chances of winning the case and $\mathrm{Pb}$ is the defendant's estimate of his chances of losing the case.

It is true that if the parties are realistic they will not go to trial as Voigt says; but in reality the probability of an agreement that does not depend much on being realistic - finally, when they negotiate, the parties do not know how realistic their forecasts are- but on the relation between the parties' forecasts, regardless of whether those beliefs coincide with the actual probabilities of winning or losing the case.

Let's set a simple example to illustrate this (see Table 1). For simplicity, let's say that the amount at issue is $Q=100$, and there are no costs of litigation or settlement ${ }^{1}$. Let us call $A$ the plaintiff, and B the defendant. Let Pa be the Plaintiff's estimate of the probability $\mathrm{P}$ of the judge's reasoning for $\mathrm{A}$, and let $\mathrm{Pb}$ be the Defendant's estimate of this happening (and thus having to pay $Q=100$ ). The expected value of the amount to be received by $A$ (paid by $B$ ) is $P a{ }^{*} Q$ or $P b{ }^{*} Q$ (depending on who makes the estimation). Let us first suppose that the real probability that $A$ will win (and therefore $B$ will lose) is $30 \%$.

TABLE 1. Assumption: True value of $P=0.30$

\begin{tabular}{|l|l|l|l|}
\hline & $\begin{array}{l}\mathrm{Pb}=0.20 \\
\text { (optimistic) }\end{array}$ & $\mathrm{Pb}=0.30$ & $\begin{array}{l}\mathrm{Pb}=0.40 \\
\text { (pessimistic) }\end{array}$ \\
\hline $\mathrm{Pa}=0.40$ (optimistic) & Trial & Trial & Bargain \\
\hline $\mathrm{Pa}=0.30$ & Trial & Bargain & Bargain \\
\hline $\mathrm{Pa}=0.20$ (pessimistic) & Bargain & Bargain & Bargain \\
\hline
\end{tabular}

Source: Own Elaboration

As we see, if both are realistic $(\mathrm{Pa}=\mathrm{Pb}=0.30$; Expected Values to receive/pay after trial $=30)$, the trial will not take place as Voigt says. But, if they are far from being realistic the result may be Trial or Bargain. For example, when $\mathrm{Pa}=0.40$ and $\mathrm{Pb}=0.20$ (both optimistic compared to $\mathrm{P}=0.30$ ), B will not accept to pay more than 20 to avoid trial, not enough to convince A (who asks for 40 at least), so they will go to court. And in the opposite case, being both pessimistic (again compared to reality) there is room for negotiation and they will not go to trial. The reason is that the result has nothing to do with the realism of their estimates, but on "how optimistic $A$ is with respect to B".

Let's check this in a very similar example (see Table 2). Now the parties' estimates ( $\mathrm{Pa}$ and $\mathrm{Pb}$ ) are the same as before, but the true value of $P$ is 0.01 (i.e. a new judge who will almost always say yes to the defendant). So now $A$ seems to be very optimistic (not realistic in any case), and $B$ is very pessimistic (not realistic at all either).

\section{TABLE 2. Assumption: True value of $P=0.01$}

\begin{tabular}{|l|l|l|l|}
\hline & $\begin{array}{l}\mathrm{Pb}=0.20 \\
\text { (pessimistic) }\end{array}$ & $\begin{array}{l}\mathrm{Pb}=0.30 \\
\text { (very pessimistic) }\end{array}$ & $\begin{array}{l}\mathrm{Pb}=0.40 \\
\text { (extremely pessimistic) }\end{array}$ \\
\hline $\mathrm{Pa}=0.40$ (optimistic) & Trial & Trial & Bargain \\
\hline $\mathrm{Pa}=0.30$ (very optimistic) & Trial & Bargain & Bargain \\
\hline $\mathrm{Pa}=0.20$ (extremely optimistic) & Bargain & Bargain & Bargain \\
\hline
\end{tabular}

\footnotetext{
${ }^{1}$ We will also assume that there is no risk aversion, strategic behavior or other distortions.
} 


\section{Source: Own Elaboration}

In this second example, although both $A$ and $B$ are far from being realistic (compared to the true chances of winning or losing the case), the results are exactly the same. The reason is clear. What allows the parties to bargain is that the minimum amount that $A$ is willing to receive -not to go to trial- is not greater than what $B$ is willing to pay to $A$ (in our example, that equals $\mathrm{Pa}<\mathrm{Pb}$ ). Such negotiation does not depend on whether their estimates are realistic or not, but on the relationship (and difference) between such estimates. In both tables, it is evident that if the plaintiff and defendant estimates coincide (on the diagonal), no matter if they are right or not, they will bargain instead of proceeding to trial.

Such estimates will depend on many factors such as the perceived quality of the judicial system, the tools lawyers have to present evidence, and their ability or willingness to spend on the case. And to a great extent, those estimates will depend on the information transmitted by lawyers to their clients and in general on the amount of information that the parties have, a matter we shall return to in the next Section of this paper.

\section{- Estimation of the Litigation and the Agreement Costs}

The private costs of a legal dispute can be direct (lawyers and experts' fees, transport, court fees, etc.) or indirect (for not being able to make use of the assets under dispute, for investment opportunities lost, for lost revenues for attending the trial, for other possible uses of the time spent there, etc. $)^{1}$.

At this point, it should be remembered that the demand for court services is a supply-induced demand. In the decisionmaking process, clients usually have much less information than lawyers about the stages of the proceedings, the time that can elapse until a final judgment is reached, the private costs of the proceedings or the possibility of an out-of-court settlement. And yet, in case of a conflict, this data is considered essential when deciding whether or not to sue.

As we will see later, the lack of knowledge among the European citizens - potential users of the courts - about the judicial system in their own country, the costs they will have to bear or the possibility of reaching an out-of-court settlement is high overall and can be extremely high in some EU member states. Furthermore, the estimation of costs by the client may be influenced by the strategic behavior of lawyers, as their incentives to go to trial or to bargain may be different from those of their client's.

\section{- Adverse Selection and Moral Hazard / Principal-Agent Problems}

The theory of asymmetric information, and in particular the analysis of Adverse Selection and Moral Hazard, are a great help in studying the problems with efficiency that occur in the legal services market. When hiring the services of a lawyer, given the client's ignorance about the legal system, the latter suffers, in the first place, an "Adverse Selection" problem: being perhaps the first time that he hires a lawyer, and without much more information than the one given by his lawyer, the client has serious difficulties in evaluating his qualifications and assessing if the lawyer he is hiring is the one that best suits his interests. This same asymmetric information produces a "Moral Hazard" problem because the client (the "principal") is not in a position to determine if the actions taken by his lawyer (the "agent") are the ones that best suit his interests.

\section{- Possibility of Reaching Out-of-Court Agreements}

As pointed out by Gravelle (1990), this is a determining variable for court demand. This effect will depend on whether these agreements are considered to be close substitutes for litigation (Murrel, 2001), and in particular whether there are alternative dispute resolution systems (Voigt 2004). This issue is discussed by Pastor (2016) who focuses on the possibility for judges to encourage this option and on the willingness of lawyers to influence their clients in favor of this way of resolving the conflict; which, in turn, depends to a large extent on the interests the lawyers have, and which may not coincide with those of their clients.

\footnotetext{
${ }^{1}$ For a discussion on the different types of public and private costs, and estimates using Spanish Data see for example Pastor and Vargas (2001) and Pastor (2016).
} 


\section{BIG Data: A New Approach to the Demand for Court and Legal Services}

\subsection{What is Big Data}

Big Data used to be defined in terms of the three Vs (Volume, Velocity and Variety) although some added other Vs (Veracity, Visibility, Value.... $)^{1}$.

Unfortunately, scalability problems caused by the exponential growth of digitized data have conditioned the definition, goals and research areas in Big-Data, reducing it to just a technological tool (3vs or 5vs definition).

It is estimated that $95 \%$ of the information used today has been generated only in the last two years, thanks to the improvements in storage capacity and the cost reduction of computing tools. This data is generated and stored either on a planned or an unplanned basis, as a result of the regular activities of different agents (individuals, companies and entities of all types). We produce this data directly and indirectly second after second. It is generated in several ways. The first, and the one that we are more interested in this paper, is the one made by people: using WhatsApp, social networks, forums and chats; when googling or searching other internet platforms; when using mobiles, the GPS or the email; by consulting other users online, or simply visiting a web page (with the "cookies" we accept). Other forms are by bank transactions and purchases, from machine to machine (power consumption or vital sign readers) and with biometric data generated by security or intelligence agencies. This data is being sent to the internet in real time, leaving a "digital fingerprint" 2 that can potentially be used to trace the owner of that data.

Big Data begins to give the ordinary citizen an enormous amount of information about what happens to other citizens in similar circumstances, the decisions they made, the variables taken into account, and the mistakes they made and their consequences. Therefore, it offers the possibility to take advantage, practically for free and in real time, of the experience of thousands of citizens about legal proceedings and their outcomes, both in the most formal aspects (such as the money invested and received, or the time until they got a court decision) and others more indirect or subjective (such as stress, discomfort, costs of travel or paperwork or others not normally accounted for), which ultimately affect the demand for court services; and with the additional advantage of coming from the actual users' experience and not just from the information offered by the lawyer.

As we will see in the next Section, this access to this massive amount of information is crucially changing the criteria and the logic of the demand for court and legal services in general.

\subsection{How the Logic of the Demand for Court Services Changes in the Big Data Environment}

Although the academic literature shows indicators to describe the functioning of the judicial system (indicators of productivity, quality, delay, congestion...) these studies are not usually available to most judicial operators and, more importantly, this information is not usually at the citizens and lawyers' disposal when deciding what their behavior in relation to this market will be. Rather, the statistics that have been more available to date have been opinion polls, especially those on television or newspapers.

Evidence indicates that citizens have little information about what possible outcomes legal proceedings may have, what costs he may have to bear, or whether there are other alternatives to resolve the conflict. And they are often unaware of the fact that the judge can order the losing party to pay the expenses of the winning party, or that on that money can be imposed an income tax, even if the money goes to cover the lawyers' fees.

Eurobarometer 2013 data shows that, even in the best situated countries, the percentage of citizens who do not feel informed about the justice system in their country exceeds $50 \%$, and that this proportion can reach $80 \%$ in some countries (see Figure 1).

\footnotetext{
1 The first definitions of Big Data or Massive Data made reference to how to make use of enormous datasets, and their analysis and assimilation, which allowed obtaining information and knowledge that could not have been known, stored or analyzed with the traditional methods and technology.

${ }^{2}$ Also called device fingerprint, machine fingerprint or browser fingerprint is a compact summary of software and hardware settings collected from a remote computing device.
} 
Figure 1. How well informed do you feel about the justice system in your country?

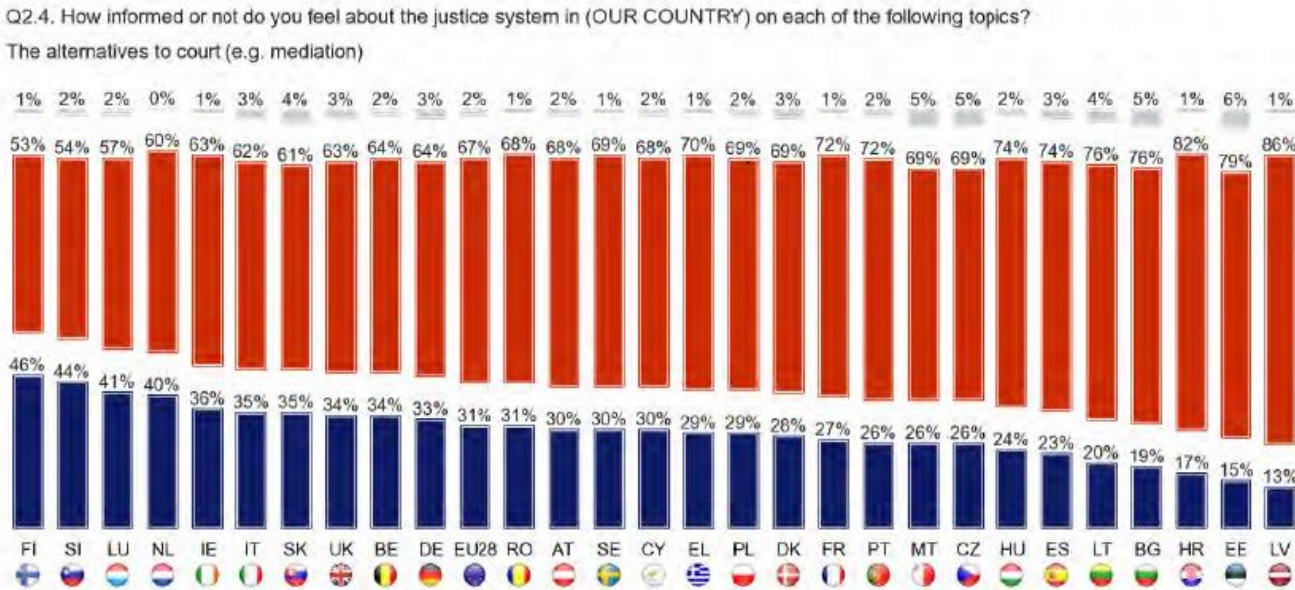

- Total 'Informed'

Dotal 'Not informed'

Don't know

Source: Eurobarometer 2013. See the symbols in the Annex.

Moreover, the percentage of citizens who do not have information on the costs of proceedings is quite high, up to $85 \%$ of the population in some countries (see Figure 2).

Figure 2. How informed or not do you feel about the justice system in your country about the cost of proceedings?

Q2.2. How informed or not do you feel about the justice system in (OUR COUNTRY) on each of the following topics?

The costs of proceedings

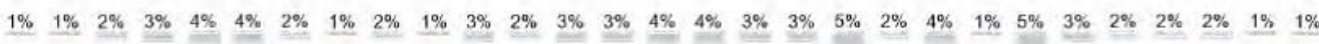

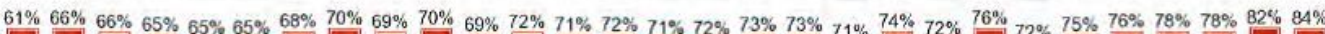

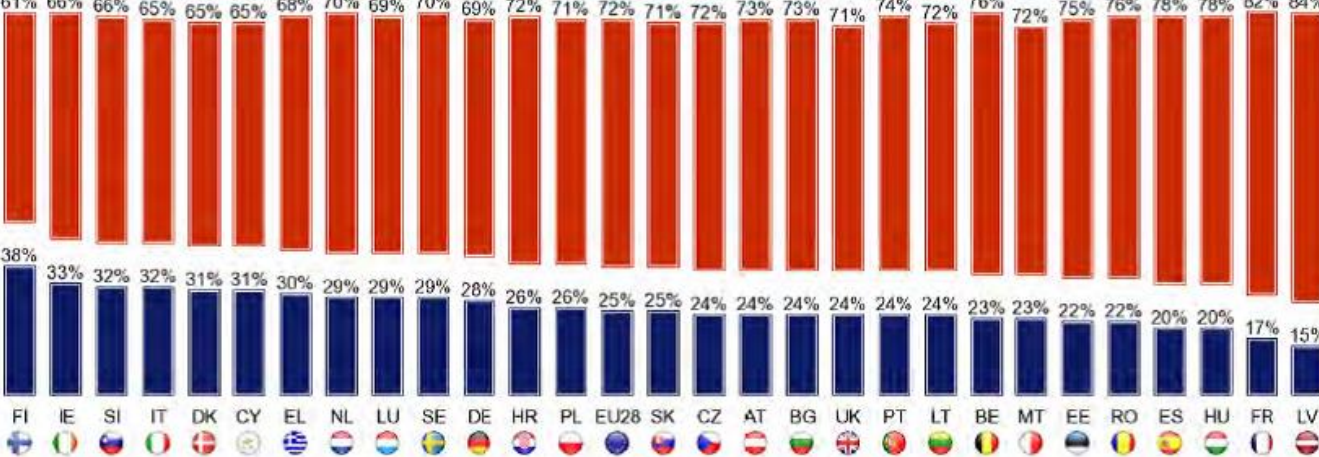

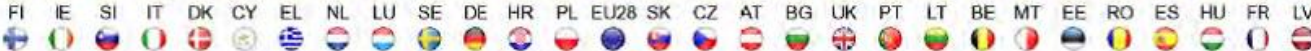

$$
\text { - } \text { Total 'Informed' }
$$

Source: Eurobarometer 2013. See the symbols in the Annex.

In addition, European citizens can have huge differences in their trust in their judicial system and, in particular, in their belief that not all citizens can go to court to defend their rights, from $6 \%$ in Luxembourg to $32 \%$ in Spain or $40 \%$ in Italy (see Figure 3). 


\section{Figure 3. Do you agree or disagree that in your country}

\section{All citizens can go to court to defend their rights?}

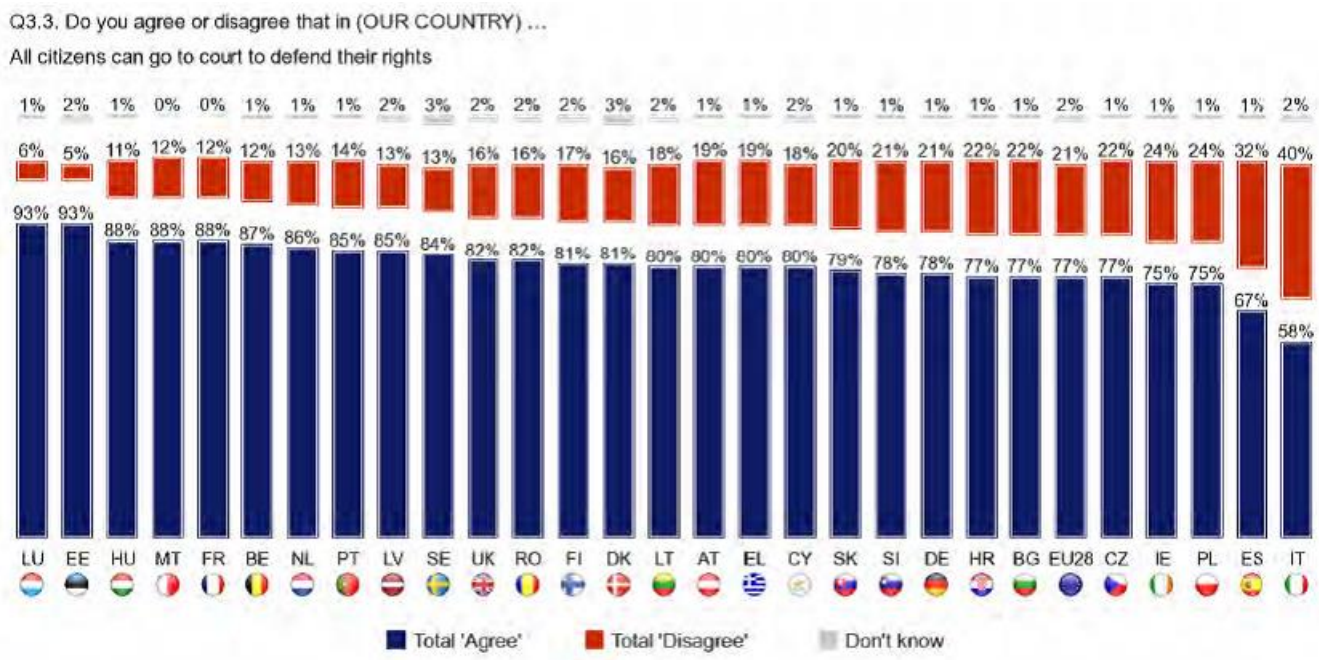

Source: Eurobarometer 2013. See the symbols in the Annex.

\section{- Estimation of the Probabilities and the Litigation Costs in the Big Data Environment}

At this point, it is crucial to take into account that the demand for court services is a supply-induced demand. At present, the client suffers from having little knowledge about proceedings, so the lawyer is almost the only source of information when facing the choice of going to court or not ${ }^{1}$. And that legal advice is mainly influenced by two factors. First, by the lawyer's own estimates of the possible outcome that this particular case may have. And secondly, by the lawyer's incentives to go to court -instead of reaching an agreement, for example- which may not match with that of the client².

However, the increasing use of Big Data not only allows for more and better information obtained from several sources ("actual users"), but it also changes the way the client deals with the legal proceedings. The logic of Big Data motivates citizens to get first-hand information about court proceedings and other possible ways of resolving the conflict, and also on the costs incurred by hundreds of users; everything in real time, detailing the type of matter, the amount at issue, the location or any other variable that may alter the outcome, variables that will change their decision to go to court, and the strategies to follow.

The logic of big data is changing both the estimates and the process of estimation of the parties to the conflict about the costs and the probability of success in their particular cases and other important data. In the previous Section we showed that the demand for court services depends on the difference between parties' estimates of their chances of winning the case. Now, in the context of Big Data, these estimates will be increasingly similar -as this same information will be available to both parties- which is likely to increase the number of cases solved by out-of-court settlement and will lead to a reduction in the demand for court services. In addition, it is possible that the demand for legal services will remain relatively constant since both forms of resolution of the conflict -litigation or negotiation- require lawyers' advice.

\footnotetext{
${ }^{1}$ Something similar happens with the demand for health services. That demand is also supply-induced as the patient has little knowledge of the available treatments in his particular case and what the possible outcomes are, so he cannot assess the options or decide without the doctor's advice.

2 The incentives of lawyers to a fast process (through out-of-court agreement, for example) will be very different if they charge contigent fees than if they are paid on an hourly basis or a flat fee.
} 


\section{- Actual Costs of the Proceedings for the Client with Big Data}

The logic of Big Data not only changes the "estimates" of the costs of the proceedings. In our view, the costs themselves, especially those relating to lawyers' fees, are also changing, because the market is becoming more competitive and the fees per case tend to fall; and because agreements will move towards contingency fees in some types of procedures, especially in those countries where current fees depend mainly on the type of matter or the time devoted, regardless of the final outcome.

As an example, we can mention the case of Spain where, as a result of the housing bubble and the economic recession, there was a huge number of evictions (with their corresponding court cases ${ }^{1}$ ). And almost at the same time, since 2016 there has been an explosion of lawsuits against the banks, after the final ruling by the EU on the so-called "floor clauses", ordering Spanish banks to repay all earnings from "abusive" mortgages. This has produced a large niche-market that has been exploited by some law firms that have specialized in this type of business, accumulating hundreds of similar lawsuits.

This specialization reduces the costs of the process which, in the event of a reduction in prices, tends to increase litigation even more. But why, although there have been many other massive conflicts in the past, ${ }^{2}$ they did not end in a lawsuit? To a large extent, the reason is that citizens do not have sufficient confidence in the judicial system, because of the enormous uncertainty about the costs and the possible outcomes of court proceedings. Thanks to Big Data, the citizen starts to find relevant information on the internet, not only the one offered by law firms (something relatively new in Spain) but especially the one coming from ordinary citizens who share their experience on how they started the claim, what procedures were followed, what obstacles were encountered and how they were resolved, so his lack of information about the judicial system is being greatly reduced. At the same time, the costs of finding information is also significatly declining. This information is not yet structured, but is available almost free of charge to anyone with minimal internet skills.

All of this has meant that, in order to finally attract these potential clients at least in this type of litigations, Spanish lawyers are modifying the way they charge their fees onto a contingency fee system. That is, they advertise themselves as riskfree services, paying the other party's costs in case of losing the case. This type of fees increase efficiency (because they encourage only those expenses that will be productive for the outcome), improve the outcome for the client (for the incentives given to lawyers) and in general reduce market uncertainty.

Thus, as prices are being reduced also for this reason, access to justice may increase (both in courts and by out-of-court agreements) and the consumption of legal services will probably be higher as is happening in Spain in these last two years in this type of matters.

Additionally, thanks to the logic of Big Data, a large number of cloud-based legal practice software applications have now appeared allowing lawyers to improve their performance by reducing their search time for legislation and legal precedents, also including tools for time tracking, billing and case management of cases, among others ${ }^{3}$. Moreover, in recent times, and as a result of the increasing power of computers, large law firms start to incorporate Big Data in their private activity and their internal operations, gathering information about thousands of their own prior clients, which allows them to estimate their chances of success in each specific case, depending on which court the case has been assigned to and other specific factors 4 .

This information allows lawyers to increase their chances of success at a lower cost, which will reduce the "cost of production" of their services. Ceteris paribus, this could also mean a lower price for the client.

Of course, all this will result in price reductions, depending on how much more competitive the market becomes. If, as we anticipate, competition in the legal services market increases, the price reduction will tend to increase the use of court

\footnotetext{
1 See for example CGPJ (2016).

${ }^{2}$ With telephone companies, utilities and other basic services that accumulate thousands of claims each year.

${ }^{3}$ See for example http://www.capterra.com/legal-case-management-softwarel .

${ }^{4}$ Some studies are concerned about this software, because it handles private data about millions of citizens and their cases, and is being used by (lawyer) firms who, despite knowing the legislation on data protection, are not used or prepared to protect that information, so it could easily be captured via the internet for unintended uses.
} 
services, perhaps increasing congestion and delay, and generating interactions that partially compensate for the initial increase in consumption of court and legal services.

\section{- Adverse Selection and Moral Hazard/Principal-Agent Problems in the Big Data Environment}

To illustrate the logic of Big Data on these two issues it may be useful to recall how Amazon has changed the logic of market functioning in a large number of goods and services. Ten years ago if a person wanted to repair an appliance at home, he had to go to the nearest hardware store, get the necessary tools and spare parts, and then repair it himself, or hire the services of a technician. In this context, in the first place Amazon makes available information to the customer about dozens or hundreds of suppliers of such tools and spare parts, which can be compared thanks to the opinions and recommendations of other users; so it is now possible for the consumer to compare sellers before deciding and he will probably end up buying from some other supplier. Additionally, thanks to the logic of Big Data, the customer learns that there are multiple options for this replacement and even different alternatives, so he may not buy the same tools and spare parts he would have bought before. Finally, he can implement the logic of Big Data, available on the internet platforms, to learn how to do the repair himself, so he may not hire the same technician as before, or perhaps he will hire another who offers different alternatives to what he had initially thought. In short, the logic of Big Data changes the goods that are bought and how they are bought, the suppliers that are chosen, and finally, the services that are contracted. And more importantly, Big Data changes the logic of the customer's behavior and the procedure followed when deciding how to solve his initial problem.

A similar reasoning can be followed to forecast the effect that the logic of Big Data will have on the demand for lawyer services.

First, with the greater access to available information, the problem of adverse selection will be reduced, as potential clients will be able to access the internet and obtain very extensive information, from actual users, about the type and quality of the services offered by different law firms, which will allow them to better choose the services they need to contract.

And secondly, although the individual citizen will only have few additional tools to carry out the monitoring of his own lawyer's performance, by accessing the internet platforms he will be able to get comments from other users -each with a different level of legal knowledge- who share their own experience; for example about a mistake they observed in their lawyers's work; or whether or not the procedural deadlines were met. This will be perceived by law firms as a greater control over their work, bearing in mind that this information will now be available to other current or future clients. This will change the lawyers' performance, their strategies in court and the overall effectiveness of their work.

Obviously, this massive amount of additional information available to plaintiffs and defendants incentivates in turn the suppliers (the lawyers) to change other behaviors in the market and in relation to their particular clients. Keeping other factors constant, they will not only improve their advice to clients during the development of the case, but will also provide with more and better prior information to prospective clients on the possible costs and outcomes of the different options available to resolve the conflict, in or out of court.

So, with the logic of Big Data, the potential customer begins to make decisions in a different way. The client learns that his decision must be made after searching for the relevant information on the internet platforms, comparing the different services, studying the different possible outcomes both when going to court and when initiating an out-of-court settlement, taking into account all variables that may affect the outcome (which may depend on his own behavior or on his lawyer's) and finally evaluate each available alternative in all the dimensions that may interest him (time, money, stress, opportunity costs of resources invested, etc.). This will allow him to follow a decision-making process that maximizes his interests, both when hiring a lawyer and when deciding whether or not to proceed to court, taking into account the specific characteristics of his particular case. 


\section{Conclusions}

As we have seen, the logic of Big Data changes the way citizens, and the potential clients of court services in particular, make use of the massive amount of information available on the internet. The use of this huge amount of information is drastically changing the expectations of the possible users regarding costs and the court outcomes. It also changes the structure of "production costs", both in monetary terms and in the number of hours invested, and the efficiency and the effectiveness of the lawyers' services (and probably also the behavior of judges ${ }^{1}$.

These advantages can be passed on to the client, therefore increasing the consumption of these services, together with the greater and better information provided. But the biggest contribution of the logic of Big Data is that it is significantly changing the process of evaluating the decision to go to court and the way in which legal services are contracted.

In this paper we contribute to the Law and Economics literature by showing how the logic of Big Data not only provides the parties to a dispute with more information, but also introduces new criteria to take into account, and a new way to approach the decision of going to court or to reach an out-of-court agreement, thus modifying the demand for court and legal services in several ways.

First, we have shown that the estimates of plaintiffs and defendants regarding the costs and possible outcomes of the proceedings will be closer to each other, which, according to economic theory, will reduce the number of cases going to court (lowering demand), by making out-of-court agreements more attractive. This will not only reduce private and public costs, but will also reduce congestion, thereby improving the functioning of the courts.

Secondly, following economic theory, we can predict that reducing uncertainty will significantly change the decisions about going to trial. Some prospective plaintiffs who would have filed a claim will not do so, and some others will conclude that it is worthwhile to enter into litigation.

In addition, we have shown that not only the estimates of the costs of going to trial will change, but that the costs themselves will tend to decline. With Big Data, citizens are more likely to compare prices and services from different law firms, which contributes to a more competitive market. Although the proportion of this savings that the client enjoys is dependent on how the market structure evolves, it is clear that the logic of Big Data is changing lawyers' behaviour and also their fees onto result based fees at least in some civil matters. This not only reduces the cost of these services to the client, but also increases the specialization, increases the quality of the services offered by lawyers and the efficiency of their production, and reduces the search costs for clients. Price reductions for clientes incentivate the consumption of lawyers' services and court services in general.

Furthermore, the fact that the logic of Big Data allows the citizens to use actual users' information about the different options available, and their pros and cons, will reduce both the adverse selection problem and the principal-agent problem as well. To be more attractive in the market, law firms will give more and better information to their clients on the different strategies and possible outcomes, and the advantages or disadvantages of going to court, or reaching an out-of-court settlement.

Thus, the logic of Big Data is improving the quality of court and legal services, increasing efficiency in the judicial sphere, and increasing access to justice, which is definitely improving the well-being of citizens.

Since there are many opposite effects on supply and demand as a consequence of the incorporation of Big Data into the judicial logic, it is not possible to determine a priori whether the logic of Big Data increases or reduces the demand for court services. In the Short-Term, we believe that it will increase the number of lawsuits -given a number of conflicts- mainly due to the lower costs faced. However, in the Long-Term it is possible that the combined effect on the demand is negative: with more realistic expectations, the theory of litigation indicates that the use of court services will be reduced by increasing out-of-court agreements, provided that the necessary mechanisms for that are available.

\footnotetext{
${ }^{1}$ In this context, judges may have a tendency to pass sentences similar to those of their colleagues' not to appear as an "outlier". That does not necessarily mean an increase in the quality of the sentences, but the reduction in randomness and uncertainty does have positive effects on the system.
} 
In addition, being easier to claim rights in court and less uncertainty about court outcomes, there will be less incentive to commit certain specific types of offences ${ }^{1}$, which may also contribute to a lower level of litigation and a lower congestion. Of course, the partial compensatory effect due to the interaction between supply, demand and delay should be taken into account.

We believe that the major contribution of this paper is to show that Big Data is significantly changing the logic of behavior of both consumers and providers of court and legal services in general, leading to a change in the decision making criteria by all the agents involved. Not only does it change the way legal services are offered. As we have seen, users of court services are beginning to follow a decision-making process that starts off by looking for the relevant information that is beginning to be available on the internet. Citizens are starting to learn that now, in the judicial sphere, they can more directly assess each available alternative both in terms of benefits and of direct and indirect costs, in all relevant dimensions, taking into account the experience and advice of thousands of previous litigants, to adjust their decision based on the specific characteristics of their particular case.

\section{References}

[1] CGPJ (2016). Memoria que el Consejo General del Poder Judicial eleva a las Cortes Generales. España. Consejo General del Poder Judicial, Secretaría General.

[2] Gould, J. (1973). The Economics of Legal Conflicts. Journal of Legal Studies, 279.

[3] Gravelle, H. S. E. (1990). Rationing Trials by Waiting: Welfare Implications. International Review of Law \& Economics, 10(3).

[4] Kaplow, L. \& Shavell, S. (2002). Economic Analysis of Law. Handbook of Public Economics 3(25). pp. 16611784. A. J. Auerbach \& M. Feldstein (Eds.). Elsevier Science B.V.

[5] Landes, W. (1971). An Economic Analysis of Courts. Journal of Law and Economics. April.

[6] Landes, W. \& Posner, R. (1979). Adjudication as a Private Good. Journal of Legal Studies, 8, 235-284.

[7] Mora Sanguinetti, J. \& Garoupa, N. (2015). Do Lawyers Induce Litigation? Evidence from Spain, 2001-2010. International Review of Law and Economics, 44-C, pp. 29-41.

[8] Pastor Prieto, S. (2016). Análisis Económico de la Justicia y Reforma Judicial. Valencia. Tirant Lo Blanch (Eds).

[9] Pastor Prieto, S. (1993). ¡Ah de la Justicia! Política Judicial y Economía. Madrid. Civitas (Eds),

[10] Pastor Prieto, S. \& Vargas Pérez, C. (2001). El Coste de la Justicia. Datos y un Poco de Análisis. Cuadernos de Derecho Judicial, 15, pp. 29-72.

[11] Posner, R.A. (1973). An Economic Approach to Legal Procedure and Judicial Administration. II Journal of Leal Studies, 2.

[12] Priest, G. (1989). Private Litigants and the Court Congestion Problem. Boston University Law Review, 69, 527-559.

[13] Rosales Lopez, V. (2008). Economics of Court Performance. An Empirical Analysis. European Journal of Law and Economics, 25(3).

[14] Rosales Lopez, V. (2017). Demanda y Oferta de Justicia Civil en España. Papeles de Economía Española, 151.

[15] Rosales Lopez, V. \& Jimenez-Rubio D. (2016). Empirical Analysis of Civil Litigation Determinants: the Case of Spain. European Journal of Law and Economics. 1(18)

\footnotetext{
${ }^{1}$ For example, in Spain some banks begin to eliminate the so called "abusive commissions" in mortgages to new clients and even some of them offer compensations to former ones, in exchange for refraining from suing them.
} 
[16] Shavell, S. (1982). The Social versus the Private Incentive to Bring Suit in a Costly Legal System. Journal of Legal studies, XI, June, pp. 333-9.

[17] Shavell, S. (2004). Foundations of Economic Analysis of Law. Cambridge, Massachusetts, London, England, Harvard University Press.

[18] Vargas Pérez, C. \& Peñaloza Figueroa, J.L. (2005). The Duration of Civil Cases. A Survival Analysis. Perspectivas. Revista de Análisis en Economía y Comercio Exterior. 1(1), México. (Available at http://eprints.ucm.es/42178/)

[19] Vargas Pérez, C. \& Peñaloza Figueroa, J.L. (2004). Qué Costes Económicos y Sociales Comporta la Ejecución de Sentencias Judiciales. Revista Cuadernos de Estudios Empresariales. 15. pp. 261-269. Madrid.

[20] Voigt, S. (2014). Determinants of Judicial Efficiency: A Survey. European Journal of Law and Economics. February.

Annex. Symbols in Figure 1, Figure 2 and Figure 3.

$\begin{array}{llll} & & \text { ABBREIATIONS } & \\ \text { BE } & \text { Belgium } & \text { LV } & \text { Latvia } \\ \text { BG } & \text { Bulgaria } & \text { LU } & \text { Luxembourg } \\ \text { CZ } & \text { Czech Republic } & \text { HU } & \text { Hungary } \\ \text { DK } & \text { Denmark } & \text { MT } & \text { Malta } \\ \text { DE } & \text { Germany } & \text { NL } & \text { The Netherlands } \\ \text { EE } & \text { Estonia } & \text { AT } & \text { Austria } \\ \text { EL } & \text { Greece } & \text { PL } & \text { Poland } \\ \text { ES } & \text { Spain } & \text { PT } & \text { Portugal } \\ \text { FR } & \text { France } & \text { RO } & \text { Romania } \\ \text { HR } & \text { Croatia } & \text { SI } & \text { Slovenia } \\ \text { IE } & \text { Ireland } & \text { SK } & \text { Slovakia } \\ \text { IT } & \text { Italy } & \text { FI } & \text { Finland } \\ \text { CY } & \text { Republic of Cyprus* } & \text { SE } & \text { Sweden } \\ \text { LT } & \text { Lithuania } & \text { UK } & \text { The United Kingdom } \\ & & & \\ & & \text { EU28 } & \text { European Union - 28 Member States }\end{array}$

